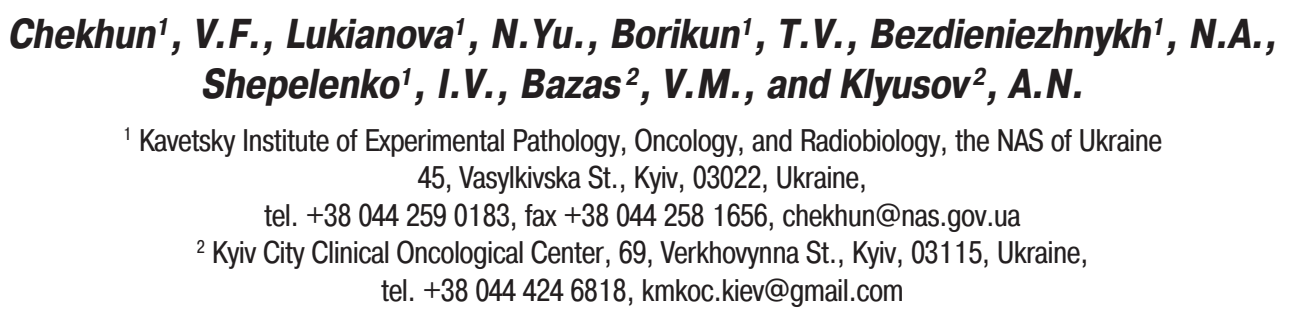

\title{
THE CLINICAL SIGNIFICANCE OF TUMOR MIR-122, -155, -182, AND -200b EXPRESSION IN PATIENTS WITH BREAST CANCER
}

\begin{abstract}
The research was aimed at identifying the relationship between the oncogenic $(-182,-155)$ and the onco-suppressive (-122, -200b) miRNAs in tumor cells with clinical and pathological characteristics of breast cancer (BC) and at establishing their clinical significance. MiRNA levels have been determined by reverse transcription polymerase chain reaction (RT-PCR) in real time. The expression of estrogen (ER) and progesterone (PR) receptors, and Her2/neu epidermal growth factor has been ascertained by immunohistochemical method. The correlation of these miRNAs expression with the disease stage, the presence of metastatic lesion of local lymphatic nodes, the differentiation degree, and the tumor molecular subtype has been established. The obtained results have confirmed the involvement of the tested miRNAs in the formation of BC malignancy degree, their association with tumor aggressiveness and have defined the prospects of further studies of the proposed miRNAs panel for their use as BC additional markers.
\end{abstract}

Keywords: breast cancer, miRNAs, and clinical significance.

Breast cancer (BC) is an actual oncology problem due to a high women morbidity in many world countries [1]. In the gender-age structure of cancer rate in Ukraine, the highest breast cancer mortality has been reported for women aged 30-74 years. Thus, working able women have a share of $37 \%$ and more than $30 \%$ in the total number of patients and died of disease, respectively, which leads to significant losses of the life potential of the female population of Ukraine [2]. The given indicators define the breast cancer as the most actual and extremely important problem of oncology, which has both medical and social significance.

(C) CHEKHUN, V.F., LUKIANOVA, N.Yu., BORIKUN, T.V., BEZDIENIEZHNYKH, N.A., SHEPELENKO, I.V.,

BAZAS, V.M., and KLYUSOV, A.N., 2017
Today, it has been established that diverse clinical patterns of breast cancer, the absence of a positive effect after standard treatment in patients of the same age with identical disease state, histological form, and tumor differentiation are related to the existence of inter- and intra-tumor heterogeneity of malignantly transformed cells population [3]. The intra-tumor heterogeneity based on genetic instability is a multilevel biological phenomenon that is considered to be a key factor in determining the tumor process both at the beginning and in the course of development of various forms of tumor progression, i.e. the disease aggressiveness [4]. According to many researchers, the intra-tumor heterogeneity plays a decisive role in the rate of tumor development, stimulates its oncogenic potential and survival of 
cells in conditions of dynamic microenvironment [5-6]. The intra-tumor heterogeneity manifests itself as difference in morphological structure, genetic and epigenetic status, as well as variability in the expression of various markers, including molecular genetic ones, among the cell population groups [6].

Despite the results of numerous studies, the correlation of tumor cells heterogeneity with aggressiveness of breast cancer malignant process requires a more detailed study. It is expedient to consider the identification of new markers that, alone or in combination with other well-known indicators, could reveal additional mechanisms of tumor growth and become the basis for evaluation of key factors of tumor progression (metastasis), namely: proliferation, adhesion, and invasion of malignantly transformed cells [7]. In this regard, the study of a new class of potential epigenetic oncomarkers - the miRNAs - becomes increasingly relevant. The miRNA is a class of small noncoding RNA (19-30 nucleotides) functioning at the post-transcription level as regulators of expression of many genes. Under physiological conditions, the miRNAs are involved in many cellular processes, including proliferation, differentiation, and apoptosis [8]. Expression of some miRNAs is associated with the initiation and progression of many types of cancer, which is the basis for their use as criteria for diagnosing the tumor progression and the dynamics of responses to therapy [9]. Due to their stability they have a significant advantage over other biomarkers, insofar as starting with the early stages of carcinogenesis, the tumors have a unique miRNA expression profile [10]. The search and identification of these tissue-specific markers with the tumor heterogeneity level taken into account is an extremely promising area of modern oncology.

This study is aimed at determining the correlation between the oncogenic $(-182,-155)$ and the oncosuppressive (-122 and -200b) miRNA expression in the tumor cells with BC clinicopathologic characteristics and at establishing their clinical relevance.

\section{MATERIALS AND METHODS OF STUDY}

In order to verify the tumor process, a histological examination of BC patient surgical material has been carried out. Having been fixed in $10 \%$ neutral formalin solution for one day, the samples were prepared in increasing concentration spirits and poured in paraffin blocks. The general tumor structure was assessed while scanning histological sections stained with hematoxylin and eosin; the histological type of tumors was determined according to the WHO International Histological Classification (2008).

An immunohistochemical study of estrogen receptor (ER), progesterone receptor $(\mathrm{PR})$ and epidermal growth factor (Her2/neu) expression in tumor cells has been made to determine the molecular subtype of tumors. As a result, the four molecular subtypes of breast cancer have been determined: the luminal A $(\mathrm{ER}+, \mathrm{PR}+, \mathrm{Her} 2 /$ neu-), the luminal B (ER+, PR+, Her2/neu+), the basal (ER-, PR-, Her2/neu-) and the Her2/ neu-positive (Her2/neu+) (ER-, PR-, Her2/ neu+). The immunohistochemical study of ER, PR, Her2/neu in tumor cells was carried out on paraffin sections (4-5 microns) using the appropriate monoclonal antibodies (ER (1D5 clone), PR (PgR636 clone), and Her2/neu (c-erbB-2 clone) manufactured in Denmark, in accordance with the manufacturer's instructions.

To detect the reaction, an EnVisionsystem (Dako LSAB2 system, Denmark) visualization system was used, according to the manufacturer's recommendations. The sections were stained with Meyer's hematoxylin. The expression of studied proteins in the cells was assessed using a light-optical microscope with further counting of the cells using the H-Score method [14].

To study the miRNA expression on the patient clinical material, the real-time reverse transcription polymerase chain reaction (RT-PCR) method was used.

From $100 \mathrm{mg}$ of BC tissue homogenate, total RNA was isolated using Ribosol commercial kit (Amplisents, Russia). The amount of isolated 
RNA was measured with the help of NanoDrop 2000c Spectrophotometer (ThermoScientific, USA). The isolated RNA purity was controlled using the ratio of optical absorption values at wavelengths of $260 \mathrm{~nm}$ and $280 \mathrm{~nm}$. The RNA was dissolved in tris-EDTA buffer and stored at $-20{ }^{\circ} \mathrm{C}$ until the PCR ran. The RT-PCR was performed on the AppliedBiosystems 7900HT FastReal-Time PCR System hardware detection system using TaqMan MiRNA Assay (ThermoScientific, USA) commercial kit for RT-PCR, in accordance with manufacturer's protocol. RNU48 miRNA was used as endogenous reference for the objectification of expression parameters.

Relative expression of the studied miRNAs was determined by the comparative dCT method (relative units). The experiment was repeated three times for each sample.

Statistical processing of the obtained results was performed using STATISTICS 6.0 statistical data processing program. The mean value difference significances were compared using the Student $\mathrm{t}$-test. The differences at $\mathrm{p}<0.05$ were considered significant.

\section{CLINICOMORPHOLOGICAL CHARACTERISTICS OF BC PATIENTS}

The study is based on analysis of the results of a survey of 215 patients with I-III stage breast cancer who received inpatient treatment at the Kyiv City Clinical Cancer Center in 2014-2016 and gave an informed consent to the use of clinical data for scientific purposes. The samples of breast cancer surgical material stored in the clinical database of the Department for Tumor Process Monitoring and Therapy Design of the Kavetsky Institute of Experimental Pathology, Oncology, and Radiobiology of the NAS of Ukraine were examined.

The tumor process stage was determined according to the international tumor classification (TNM, 6th edition, 2002, and 7th edition, 2009). According to the history of the disease, all patients were subjected to general clinical, biochemical, laboratory examinations, ultrasound
Table 1

General Clinical Characteristics
of Breast Cancer Patients

\begin{tabular}{|c|c|c|}
\hline \multirow{2}{*}{ Indicator } & \multicolumn{2}{|c|}{ Number of patients } \\
\hline & $N$ & $\%$ \\
\hline Total number of patients & 215 & 100 \\
\hline Patient age, years: & & \\
\hline Mean & \multicolumn{2}{|c|}{$56.1+5.4$} \\
\hline Age range & \multicolumn{2}{|c|}{$24-81$} \\
\hline \multicolumn{3}{|l|}{ Menstrual function: } \\
\hline Active & 60 & 27.9 \\
\hline Menopause & 155 & 72.1 \\
\hline \multicolumn{3}{|l|}{ BC stage according to TNM: } \\
\hline Stage I & 46 & 21.4 \\
\hline Stage II & 104 & 48.4 \\
\hline Stage III & 65 & 30.2 \\
\hline \multicolumn{3}{|l|}{$\begin{array}{l}\text { Metastases in local } \\
\text { lymphatic nodes: }\end{array}$} \\
\hline N0 & 149 & 69.3 \\
\hline N1-3 & 66 & 30.7 \\
\hline \multicolumn{3}{|l|}{ BC morphology: } \\
\hline Infiltrating ductal BC & 147 & 68.4 \\
\hline Infiltrating lobular BC & 68 & 31.6 \\
\hline \multicolumn{3}{|l|}{ BC differentiation } \\
\hline G1 (high) & 60 & 27.9 \\
\hline G2 (moderate) & 106 & 49.3 \\
\hline G3 (low) & 49 & 22.8 \\
\hline \multicolumn{3}{|l|}{ Molecular subtype: } \\
\hline Luminal A & 96 & 44.7 \\
\hline Luminal B & 43 & 20.0 \\
\hline Basal & 46 & 21.4 \\
\hline Her2/neu+ & 30 & 13.9 \\
\hline
\end{tabular}

survey of the abdominal cavity, mammograms, $\mathrm{x}$ ray survey of the chest cavity, puncture biopsy of breast tumors according to the standards of diagnosis and treatment of cancer patients as approved by orders of the Ministry of Healthcare of Ukraine dated July 30, 2010, no. 645 and dated June 30, 2015, no. 396.

The general characteristics of patients are presented in Table 1. 


\section{RESULTS AND DISCUSSION}

Using the resource http://mirbase.org, a panel of miRNAs involved in oncogenesis, invasion, and metastasis of breast cancer was selected.

The miRNA expression was studied depending on the main clinical and pathological parameters of breast cancer, namely: patient age, menstrual status, breast cancer stage, presence of metastases in local lymphatic nodes, tumor differentiation, its histological structure and molecular subtype.

The analysis of the results has shown that the studied cases of breast cancer are characterized by a low expression of oncosuppressive miRNA$122,-200 \mathrm{~b}$ and by a high expression of oncogenic miRNA-182, -155 (Table 2) as compared with the normal breast tissue.

The obtained data have confirmed the association of the selected miRNA panel with growth of malignant neoplasms in the mammary gland.

The expression of oncosuppressive miRNA200b and miRNA-122 in tumor cells of breast cancer patients up to 50 years old with menstrual function has been established to exceed that for the patients over 50 years with menopause twice and 1.5 times, respectively. The cells of breast cancer patients with menopause have an increased expression of oncogenic miRNA-182 and -155 (2.9 and 3.1 times, respectively).

The highest expression of oncogenic miRNA182 and -155 are observed in tumor cells of patients with the third stage of breast cancer $(4.1 \pm$

Table 2

Expression of Oncogenic and Oncosuppressive miRNAs in the Normal and in the Malignant Tumor Tissues of Mammary Gland

\begin{tabular}{|l|c|c|}
\hline \multicolumn{1}{|c|}{ miRNA } & $\begin{array}{c}\text { Normal tissue, } \\
\text { conventional units }\end{array}$ & $\begin{array}{c}\text { Tumor tissue, } \\
\text { conventional units }\end{array}$ \\
\hline miRNA-122 & $6.4 \pm 0.45$ & $1.7 \pm 0.49 *$ \\
miRNA-200b & $8.2 \pm 0.95$ & $1.9 \pm 0.08^{*}$ \\
miRNA -182 & $1.9 \pm 0.07$ & $6.5 \pm 0.78^{*}$ \\
miRNA -155 & $13.6 \pm 1.25$ & $37.8 \pm 3.73^{*}$ \\
\hline
\end{tabular}

${ }^{*} p<0,05$ as compared with the normal tissue. \pm 0.77 and $2.7 \pm 0.53)$ as compared with the patients with the second stage $(2.6 \pm 0.39$ and $1.4 \pm$ $\pm 0.35)$ and the first stage $(1.7 \pm 0.52$ and $1.9 \pm$ $\pm 0.42)$. The higher is the $\mathrm{BC}$ stage, the lower is the expression of oncosuppressive miRNA-122 and -200b (Fig. 1).

The expression of the studied miRNAs has been found to correlate with metastatic lesion of local lymphatic nodes of breast cancer patients. As can be seen from the data shown in Fig. 2, for the patients with metastases, the expression of miRNA$182,-155,-122$, and $-200 \mathrm{~b}$ is equal to $3.4 \pm 0.85$, $2.1 \pm 0.82,0.3 \pm 0.05$, and $0.2 \pm 0.03$ conventional units, respectively, while for the N0 category patients, the expression differs and amounts to $2.5 \pm$ $\pm 0.29,1.9 \pm 0.48,2.9 \pm 0.73$, and $3.6 \pm 1.3$ conventional units, respectively.

The further analysis has enabled to establish the dependence of the expression of some studied miRNAs on the differentiation and molecular subtype of breast cancer. It has been found that the expression of oncosuppressive miRNA-122 and $-200 \mathrm{~b}$ in the tissue of high-differentiated breast cancer is higher $3.6 \pm 0.73$ and $2.4 \pm 0.61$ times than that in the moderate- and low-differentiated tumors, respectively. No correlation between the expression of oncogenic miRNA-182 and -155 with differentiation for the studied cases of breast cancer has been reported.

The cells of luminal A and luminal B subtypes of breast cancer have been established practically not to differ in the expression profiles of all studied miRNAs. As can be seen from the data shown in Fig. 3, the level of miRNA-182, -155, -122, and $-200 \mathrm{~b}$ in luminal A BC cells is $2.1 \pm 0.43,1.6 \pm$ $\pm 0.73,1.75 \pm 0.64$, and $2.5 \pm 0.35$ conventional units while that in the luminal B BC it amounts to $2.5 \pm 0.28,1.89 \pm 0.31,1.56 \pm 0.11$, and $2.35 \pm$ \pm 0.3 conventional units, respectively. It has also been determined that the Her2/neu+ BC subtype tumors practically do not differ in the expression of miRNA-182, -155, and -200b from the luminal A and luminal B subtype tumors.

The most significant differences in the profile of the studied miRNAs are observed in the breast 
Fig. 1. Level of miRNA in the tumor tissue depending on the BC stage: * $-\mathrm{p}<0.5$ as compared with the normal tissue

Fig. 2. Levels of miRNA in the tumor tissue depending on metastatic lesion of local lymphatic nodes: ${ }^{*}-\mathrm{p}<0.5$ as compared with the normal tissue; $\#-\mathrm{p}<0.05$ as compared with patient without metastases

Fig. 3. Specific features of miRNA expression in the tumor tissue of various $\mathrm{BC}$ molecular subtypes: ${ }^{*}-\mathrm{p}<0.5$ as compared with the normal tissue; \# $-\mathrm{p}<0.05$ as compared with luminal subtypes
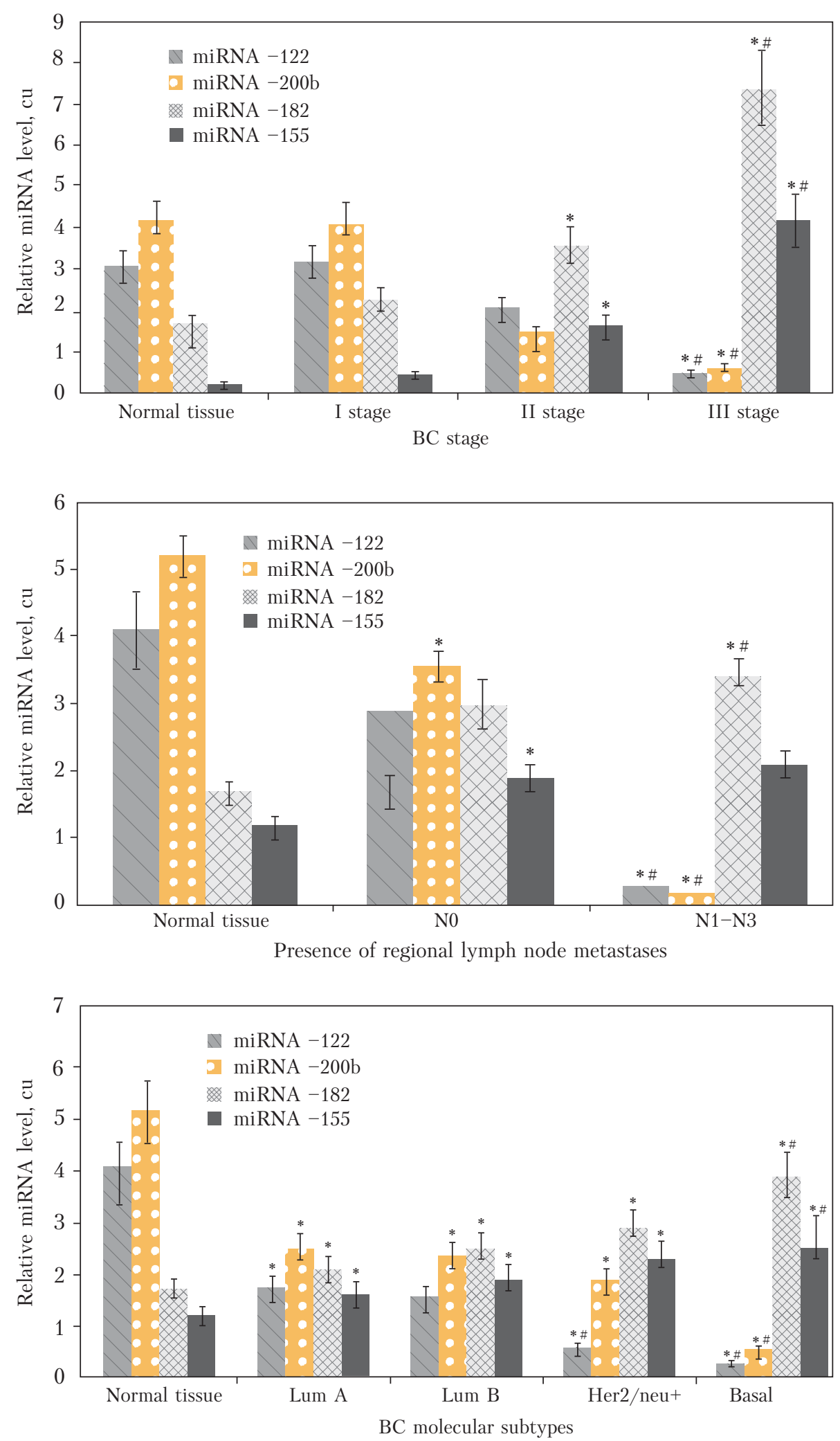

67 
cancer cells of basal subtype. In the cells of these tumors, the lowest expression of oncosuppressive miRNA-122, $-200 \mathrm{~b}(0.25 \pm 0.07$ and $0.5 \pm 0.03$ conventional units respectively) has been found as compared with the cells of other molecular subtypes. The level of oncogenic miRNA-182 and -155 in the cells of basal subtype breast cancer is higher $1.9 \pm 0.4$ and $1.7 \pm 0.15$ times, respectively, as compared with that for the luminal A, luminal B, and Her2/neu-positive subtypes (Fig. 3).

Thus, the data have shown a correlation between the level of studied miRNAs in tumor tissue and some clinico-morphological and molecular-biological characteristics of breast cancer. The dependence of the expression of oncogenic and oncosuppressive miRNAs on the stage of disease, the metastatic lesion of local lymphatic nodes, differentiation, and molecular subtype indicates their effect on the degree of malignancy of breast cancer and is associated with BC aggressiveness.

\section{CONCLUSIONS}

1. Development of malignant process in mammal gland tissue is accompanied with a decrease in the expression of oncosuppressive miRNA-122 and $-200 \mathrm{~b}$ (3.8 and 4 times) and an increase in the expression of oncogenic miRNA-182 and -155 (3.4 and 2.8 times).

2. In the cells of breast cancer patients under 50 years with preserved reproductive function, the level of oncosuppressive miRNA-122 and -200b increases 1.5 and 2 times, respectively, while for the patients with menopause, the level of oncogenic miRNA-182 and -155 increases 2.9 and 3.1 times, respectively.

3. It has been established that a low expression of oncosuppressive miRNA-122 and -200b and an increased level of oncogenic miRNA-182 and -155 are typical features for the tumors with a low differentiation, basal molecular subtype, at the late stages of breast cancer with the presence of metastatic lesion of local lymphatic nodes.

4. The obtained data testify to good prospects of further study of the proposed panel of miRNAs in order to use them as additional markers of breast cancer aggressiveness.

The research was conducted within the framework of Development and Implementation of the Prognostic Panel of Breast Cancer Biomarkers for the Personalized Monitoring of the Tumor Process project awarded upon results of the general academic competition for $R \& D$ projects (2016, state registration number 0116U006053). The obtained results have been protected by five patents of Ukraine on the utility model; four information bulletins on innovations in the health care system have been issued; the developed methodology has been implemented at the Precarpathian Clinical Oncology Center and the Rivne Oblast Cancer Dispensary.

\section{REFERENCES}

1. Siegel R. L., Miller K. D., Jemal A. Cancer statistics. California. Cancer Journal for Clinicians. 2016, 66 (1): $7-30$.

2. Buleten’ natcionalnoho kancer-reestru Ukrainu №17 «Rak v Ukraini», 2014-2015 National Cancer Institute. Kyiv, 2016. 119 p. [in Ukrainian].

3. Chekhun V.F., Sherban S.D., Savtsova Z.D. Heterohenoct' opuholi - dynamichoe sostoyanie. Onkologia (Oncology). 2012, 14 (1): 4-12 [in Russian].

4. Pareja F., Marchiò C., Geyer F.C., Weigelt B., Reis-Filho, J.S. Breast Cancer Heterogeneity: Roles in Tumorigenesis and Therapeutic Implications. Current Breast Cancer Reports. 2017, 9 (1): 34-44.

5. Ellsworth R.E., Blackburn H.L., Shriver C.D., SoonShiong P., Ellsworth D.L. Molecular heterogeneity in breast cancer: state of the science and implications for patient care. Seminars in cell \& developmental biology. 2017, 64: 65-72.

6. Chekhun V.F., Sherban S.D., Savtsova Z.D. Tumor cell heterogeneity. Experimental Oncology. 2013, 35 (3): 154-162.

7. LangJ.E., Wecsler J.S., Press M.F., Tripathy D. Molecular markers for breast cancer diagnosis, prognosis and targeted therapy. Journal of Surgical Oncology. 2015, 111 (1): 81-90.

8. Chekhun V.F., Borodai N.V., Yurchenko O.V. MikroRNK i opuholevy proces. Onkologia (Oncology). 2012, 15 (2): 136-140 [in Russian].

9. Chekhun V.F., Borikun T.V., Lukianova N.Y. Effect of 5-azacytidine on miRNA expression in human breast 
cancer cells with different sensitivity to cytostatics. Experimental Oncology. 2016, 38 (1): 26-30.

10. O’Bryan S., Dong S., Mathis J.M., Alahari S.K. The roles of oncogenic miRNAs and their therapeutic importance in breast cancer. European Journal of Cancer. 2017, 72: $1-11$.

Received 15.05.17

\author{
В.Ф. Чехун ${ }^{1}$, Н.Ю. Лук'янова ${ }^{1}$, \\ Т.В. Борікун ${ }^{1}$, Н.О. Бездєнєжних ${ }^{1}$ І.В. Шепеленко ${ }^{1}$, \\ B.М. Базась ${ }^{2}$ O.М. Клюсов ${ }^{2}$ \\ ${ }^{1}$ Інститут експериментальної патології, онкології \\ і радіобіології ім. Р.Є. Кавецького \\ НАН України, \\ вул. Васильківська, 45, Київ, 03022, Україна, \\ тел. +380 44259 0183, факс +380 44258 1656, \\ chekhun@nas.gov.ua \\ ${ }^{2}$ Київський міський клінічний онкологічний центр \\ вул. Верховинна, 69, Київ, 03115, Україна, \\ тел. +380 44424 6818, kmkoc.kiev@gmail.com

$$
\begin{gathered}
\text { КЛІНІЧНЕ ЗНАЧЕННЯ ЕКСПРЕСІЇ } \\
\text { ПУХЛИННИХ МІКРОРНК-122, -155, -182 } \\
\text { ТА -200b У ХВОРИХ НА РАК } \\
\text { МОЛОЧНОЇ ЗАЛОЗИ }
\end{gathered}
$$

Дослідження проведено з метою вивчення зв'язків експресії онкогенних (-182, -155) і онкосупресорних (-122, -200b) мікроРНК в пухлинних клітинах з клініко-патологічними характеристиками раку молочної залози (РМЗ) та встановлення їх клінічного значення. Рівні мікроРНК визначали за допомогою зворотно-транскрипційної полімеразно-ланцюгової реакції в реальному часі, експресію рецепторів естрогену, прогестерону та епідермального фактору росту Her2/neu - імуногістохімічним методом. Встановлено зв'язок експресії цих мікроРНК зі стадією захворювання, наявністю метастатичного ураження регіонарних лімфатичних вузлів, ступенем диференціювання, молекулярним підтипом пухлини. Отримані результати свідчать про участь досліджених мікроРНК у формуванні ступеня злоякісності РМЗ, іх асоціацію з агресивністю перебігу пухлинного процесу, вказують на перспективність подальшого вивчення запропонованої панелі мікроРНК для використання як додаткових маркерів перебігу РМЗ.
Ключові слова: рак молочної залози, мікроРНК, клінічне значення.

В.Ф. Чехун ${ }^{1}$, Н.Ю. Лукьянова ${ }^{1}$, Т.В. Борикун ${ }^{1}$, Н.А. Безденежных ${ }^{1}$, И.В. Шепеленко ${ }^{1}$, В.М. Базась ${ }^{2}$, А.Н. Клюсов ${ }^{2}$

${ }^{1}$ Институт экспериментальной патологии, онкологии и радиобиологии им. Р.Е. Кавецкого НАН Украины, ул. Васильковская, 45, Киев, 03022, Украина, тел. +380 44259 0183, факс +380 44258 1656, chekhun@nas.gov.ua

${ }^{2}$ Киевский городской клинический онкологический центр, ул. Верховинная, 69, Киев, 03115, Украина, тел. +380 44424 6818, kmkoc.kiev@gmail.com

\section{КЛИНИЧЕСКОЕ ЗНАЧЕНИЕ ЭКСПРЕССИИ ОПУХОЛЕВЫХ МИКРОРНК-122, -155, -182 и -200b У БОЛЬНЫХ РАКОМ МОЛОЧНОЙ ЖЕЛЕЗЫ}

Исследования проведены с целью изучения взаимосвязей онкогенных $(-182,-155)$ и онкосупрессорных (-122, -200b) микроРНК в опухолевых клетках с клинико-патологическими характеристиками рака молочной железы (РМЖ), а также выявления их клинического значения. Уровни микроРНК определяли с помощью обратно-транскрипционной полимеразно-цепной реакции в реальном времени, экспрессию рецепторов эстрогена, прогестерона и эпидермального фактора роста Her2/neu - иммунногистохимическим методом. Установлена связь экспрессии этих микроРНК со стадией заболевания, наличием метастатического поражения регионарных лимфатических узлов, степенью дифференцирования, молекулярным подтипом опухоли. Полученные результаты свидетельствуют об участии исследованных микроРНК в формировании степени злокачественности РМЖ, их ассоциации с агрессивностью течения опухолевого процесса, а также указывают на перспективность дальнейшего изучения предложенной панели микроРНК для применения в роли дополнительных маркеров течения РМЖ.

Ключевые слова: рак молочной железы, микроРНК, клиническое значение. 